\title{
FINANCIAL SITUATION OF PRE-PACKED INSOLVENCIES
}

\author{
Jaroslav SCHÖNFELD $\mathbb{1}^{*}$ \\ Department of Strategy, Faculty of Business Administration, \\ University of Economics Prague, Prague, Czech Republic
}

Received 07 October 2019; accepted 04 May 2020

\begin{abstract}
This paper is focused on the financial situation of companies entering insolvency proceedings. It does not work with all kinds of the insolvent companies, but this paper concentrates on one specific issue. The issue is pre-pack insolvencies. The main aim is to show if the financial situation is an important factor for consent to pre-pack. The pre-pack insolvencies are insolvency cases which start with an insolvency proposal which is accompanied by a reorganization plan already approved by creditors. Prepacks should help make the insolvency process quicker and enable enterprise financial rehabilitation and sustain the going concern principle. On the other hand, the procedure can hardly be successful when the financial situation of the company is extremely poor. Therefore this paper evaluates the financial situation of the companies with pre-packed insolvency in the Czech Republic. The analysis of companies was conducted over one, two or three year periods prior to the companies entering an insolvency proceeding. According to the literature, financial indicators used for evaluation are commonly EBITDA, cash liquidity, debt ratio, ROA and the Altman Z-Score prediction model. Results for the individual enterprises are summed up in this paper using basic descriptive and variable statistics. Conclusions have especially practical implications because they show financial inability of majority pre-packed cases.
\end{abstract}

Keywords: pre-pack cases, financial viability, financial ratios, Altman Z-Score, Insolvency Act, Czech Republic, insolvency proceedings.

JEL Classification: G32, G33, K22.

\section{Introduction}

The existing economic environment and increasing competition create challenging conditions for the functioning of businesses. Many businesses are not able to survive and they have to leave the market. European Commission (2013) findings show that almost $50 \%$ of new companies bankrupt within the first five years. Although business failure is part of a dynamic and healthy market, corporate bankruptcy has significant consequences. Bankruptcy does not affect only creditors and debtors, but it can affect the whole economic system (Lee et al., 2011; Peng et al., 2010). Institutions governing the insolvency processes try to minimize the

${ }^{\star}$ Corresponding author. E-mail: jaroslav.schonfeld@vse.cz 
social cost of corporate failures (Eklund et al., 2020). Rescue principle of insolvency is generally supported and there are efforts of the European Union to prefer preventive restructuring (European Parliament, \& Council of the European Union, 2016). Research conducted by European Commission (2013) proves that the second-attempted enterprises were much more successful and lasted longer than the average start-ups. These enterprises grow faster and employ more workers. It leads to a conclusion that business failure should not be a last instance of a business activity in the future. It could be seen as an opportunity for learning and improving. Pre-packed insolvencies are one of these opportunities for the improvement on one hand and on the other hand for the reduction of the social cost. The success of insolvency is closely linked to the corporate financial situation and the maturity of the business and legal environment.

This paper analyzes the financial situation of businesses entering insolvency in the form of pre-pack. The research question is based on expectations. Companies can go through the insolvency process successfully only when their viability may be expected. A key component of the future viability should be financial standing. This paper describes the corporate financial standing before an insolvency declaration. It verifies if it could be expected successful reorganization and sustainability of going concern principle because of preceding financial conditions. Although there are the papers discussing the legal environment and success of these insolvency cases there are only several research works focused on the financial situation before the insolvency proceeding solved as a reorganization (Fisher \& Martel, 2014; Leyman et al., 2011; Cepec \& Grajzl, 2019). The pre-packs have not been analyzed from this point of view yet. The previous situation could have serious impact on the pre-pack success and business viability. The paper's originality is based on an analysis which tries to solve a research gap described above. Used methods are based on generally accepted indicators describing financial situation such as EBITDA, cash liquidity, debt ratio, ROA, or Altman model predicting financial distress. Findings show the real financial situation of companies entering the insolvency proceeding as the pre-pack in the Czech Republic.

The paper has a standard structure. Introduction is followed by literature review in the solved area. The next part is dedicated to paper's aim, methodology and data. The following chapter presents results of the conducted analysis. Discussion solves especially papers' limitations because comparison is impossible due to the research gap. Conclusion summarizes the main findings respecting the institutional environment.

\section{Literature review}

There are two main ways for resolving corporate insolvency: reorganization (rescue) procedure and liquidation procedure (concursus). Since 2008, Czech insolvency law (Act No. 182/2006 Coll. on bankruptcy and settlement (Parliament of the Czech Republic, 2006)) follows the standard solutions of the debtor's bankruptcy. While legal regulation of bankruptcy is based on an age-old Central European concept, the concept of the reorganization procedure is inspired by American law (Chapter 11). According to de Weijs and Baltjes (2018) the European Union recently tried to shift the insolvency law towards more reorganizationfriendly insolvency regimes. This effort is connected with a Draft Directive on the Preven- 
tive Restructuring Framework and Second Chance (European Parliament, \& Council of the European Union, 2016) which should provide a framework for implementing reorganization without an insolvency procedure. It is called as a pre-pack approach whose survey was conducted on British cases by Xie (2016). It should enable reorganization and avoid opening a formal insolvency case although the procedure has many features of a classical insolvency process as Tollenaar (2017) highlights. In the US, such cases are resolved according to the well-known Chapter 11. Chapter 11 provides solutions for a reorganization procedure which is held as a fully formal insolvency process. Empirical evidence about Chapter 11 can be found in Ayotte and Morrison (2009).

The European Draft Directive (European Parliament, \& Council of the European Union, 2016) does not function on bases of Chapter 11 but it should replace the often strict insolvency laws and make reorganization flexible. The Direction is criticized by Eidenmüller (2017). Eidenmüller and van Zwieten (2015) had also critical remarks to former Restructuring Recommendation of the European Commission. De Weijs and Baltjes (2018) compare the reorganization to the principle-based procedure and they see liquidation as the rule-based procedure. The crucial issue for reorganization is the company's viability affected by internal and external factors; although, the process itself is governed by law. The insolvency proceeding or other kind of procedure has to balance interests of related parties. Armour et al. (2017) show that the interests of shareholders and creditors can heavily differ. Management and owners follow two ways. One way they follow is to try and rescue the company and keep the going concern principle although Ključnikov and Popesco (2017) warn that small and medium sized enterprises do not use the basic tools reducing financial risk. The second way they follow is to try to reduce their own risks and possible losses. Specific incentives of the owners and managers lead to a consequence that the pre-pack insolvency is the reorganization procedure which needs to have an approved reorganization plan by the creditors. It is a partial role of the government who should form the legal framework and the overall quality of the business environment.

The Czech government should make greater efforts in this area according to Dobeš et al. (2017). Although there were many changes in corporate and insolvency law in recent years in the Czech Republic it is not enough. The institutional environment stays a barrier (Hlavácek et al., 2015) on one hand but there are also internal company difficulties (Cera et al., 2019). Of course, many changes have brought different levels of transaction costs and, moreover, companies have faced financial difficulties due to the global economic crisis (Čámská, 2015). In the Czech Republic the financial rehabilitation (rescue) or, in other words, insolvency reorganization has not been much of a success yet (Smrčka et al., 2013). Although international experiences show better results of rescuing. It can be named empirical evidence by Ayotte and Morrison (2009) in the case of US Chapter 11 or enterprises' rescuing situation in England and Germany (Bork, 2012). The main issue is that Czech companies start the insolvency procedure almost without any owned or available property (discussed by Kislingerová et al. (2013) and proved by Čámská (2013)). It has serious consequences for creditors, especially low satisfactory rates during the insolvency proceedings discussed by Smrčka and Čámská (2017). Corporate bankruptcy does not only influence direct creditors but it also influences many other internal and external stakeholders (Branch, 2002) and the bankruptcy itself is influenced by economic cycle (Čámská \& Klečka, 2020). 


\section{Aim, methodology and data}

This chapter is dedicated to explanation of paper's aim, description of a data sample used for a further analysis and methods which will be used in the conducted analysis. The chapter is divided according to the aforementioned parts.

\subsection{Paper's aim}

The idea of this paper is to analyse the financial situation of companies which have entered the insolvency procedure with an already prepared reorganization plan. This plan has to be approved by half secured and half unsecured creditors before the insolvency proposal (paragraph 148 of the Act No. 182/2006 Coll.). The half is calculated according to the value of their claims. Within the already prepared reorganization plan, the debtor can propose to the court the insolvency administrator (trustee) who will lead this case (paragraph 25 of the Act No. 182/2006 Coll.). These insolvency cases are called pre-packed insolvencies by practitioners because they have been prepared before the insolvency proposal has been filed. In the field of corporate financial distress, we found many different approaches to identifying it. The papers on the topic are mainly focused on predicting legal bankruptcy (Appiah et al., 2015). These bankruptcy models are extremely specific and country by country, because the prediction depends on the legal framework of bankruptcy, accounting standards, and the respective country's economic environment (Levratto, 2013). The most important thing is that the event of bankruptcy is a real corporate financial situation which can be monitored and evaluated. This means that what is crucial is not the event of bankruptcy but the event of financial deterioration which results in financial distress. According to Farooq et al. (2018) financial distress can be divided into three adverse stages: profit reduction, mild liquidity and severe liquidity.

This paper is focused on the real financial situation of the companies which entered the insolvency proceedings as the pre-packed insolvencies. As it was written pre-packed insolvencies are already agreed by the creditors. It means that there is a trust that the enterprise can be viable and survive in the long run. One crucial component for the viability is the financial situation. It leads to an idea that pre-packed insolvencies should not be in disaster financial standing. This paper will prove the real financial situation and show if the financial situation is crucial for an approval of the reorganization plan. Results can show that the financial situation is not the key component for the creditors and they approve the reorganization regardless of the financial conditions.

\subsection{Data sample}

The paper's analysis is based on a data sample filtered from the corporate database Bisnode MagnusWeb (n.d.). This database is pre-paid for its users and contains complex data describing Czech and Slovak entrepreneurial entities. The most important part are obligatory published annual financial statements. This data sample contains companies which entered insolvency with the already prepared reorganization plan. For the purpose of this paper, these cases are called pre-packed insolvencies. The sample does not contain all pre-packed 
insolvencies because of the unpublished financial statements. Financial statements whose unavailability is analysed by Bokšová and Randáková (2013) are a necessary input to determine an enterprise's financial characteristics. The final sample consists of 53 enterprises (legal entities) which present all entities of a kind required publishing their financial statements in the Czech Republic. It is not possible to obtain a larger data sample alternatively.

The final data sample consists of 120 annual financial statements. The data disclosure is not regular because 3 years before insolvency there are available the financial statements of 48 companies, 2 years before insolvency 42 companies and 1 year before insolvency already only 30 companies published their statements. The decreasing number of the companies shows that the companies are less likely to publish their financial statements the closer in time to their respective insolvency proceeding. It is evident that the data disclosure is not regular.

Table 1. Sample structure - company's size (measured by annual sales in mil. CZK) (source: author based on Bisnode MagnusWeb)

\begin{tabular}{|l|c|c|c|c|}
\hline & $\begin{array}{c}\text { 1 year before } \\
\text { insolvency }\end{array}$ & $\begin{array}{c}2 \text { years before } \\
\text { insolvency }\end{array}$ & $\begin{array}{c}3 \text { years before } \\
\text { insolvency }\end{array}$ & Total \\
\hline$<=49.999$ & $43.3 \%$ & $42.9 \%$ & $41.7 \%$ & $42.5 \%$ \\
\hline $50.000-99.999$ & $6.7 \%$ & $7.1 \%$ & $14.6 \%$ & $10.0 \%$ \\
\hline $100.000-499.999$ & $33.3 \%$ & $26.2 \%$ & $22.9 \%$ & $26.7 \%$ \\
\hline $500.000-999.999$ & $6.7 \%$ & $11.9 \%$ & $10.4 \%$ & $10.0 \%$ \\
\hline $1.000 .000+$ & $10.0 \%$ & $11.9 \%$ & $10.4 \%$ & $10.8 \%$ \\
\hline Total & $100.0 \%$ & $100.0 \%$ & $100.0 \%$ & $100.0 \%$ \\
\hline
\end{tabular}

The analyzed sample can be characterized according to the company size or the industry branch. The company size can be expressed by taking into account owned property, achieved sales, and/or number of employees. The value of owned property highly depends on the industry branch and on the level of depreciation and amortization. Although, the value of the owned property and the number of the employees stay stable even when financial performance deteriorates and the company is coming closer to insolvency. However, the value of annual sales usually decreases when the enterprise is coming closer to insolvency. The sample structure, expressed by the annual sales in millions of CZK, is presented in Table 1.

The highest percentage share has the group of the smallest companies with annual turnover below 50 million CZK (over 40\%). The official exchange rate to euro announced on 6 August 2019 by the Czech National Bank was 25.775 CZK = 1 EURO. While 25\% of the sample is created by the turnover of over 100 million CZK. Unexpectedly, the sample does not significantly change its structure during the analyzed time period. There are some shifts between the three categories - from 50 million to 1,000 million CZK. While, the prevalence of available data decreases during that time. Surprisingly the value of annual turnover does not decrease and the company size structure stays stable.

Almost $50 \%$ of the analyzed companies are classified by CZ-NACE as CZ-NACE C Manufacturing industry and $25 \%$ of the analyzed companies are classified as CZ-NACE F Con- 
struction industry. The remaining analyzed companies are from either the retail industry or other sectors and total 3 or less companies.

Due to the quantitative data analysis, normality was tested. Kolmogorov-Smirnov and Shapiro-Wilk tests were conducted with the result that the data does not have normal distribution. The consequence of such a result is that any further analysis needed cannot be conducted using parametric tests because they can only be used in situations where there is the normal distribution of data. Therefore, in this case the implemented research methods will be basic descriptive statistics accompanied by relative frequencies of polarity. The relative frequencies of polarity compare positive and negative values of chosen indicators or of key variables, which are the part of these indicators. These indicators are presented in the following chapter.

\subsection{Financial characteristics}

The financial situation can be evaluated by many tools and methods. The main reason for this is that financial performance is based on many factors referred by Kaplinski (2008) such as, the company's financial structure, its financial liquidity, its solvency, its capability to adapt, its economic sources, its capability to generate profit and/or its capability to maximize its own market value. The most popular tool of financial analysis is the method of financial ratios (Jordan et al., 2011; Appiah et al., 2015). There is a critique that financial ratios do not include all the relevant information and therefore some authors suggest to use market information (Balcaen \& Ooghe, 2006). Market information can hardly be used in the Czech Republic because the capital market is not too developed and its liquidity is highly limited. None of the companies included in the sample are or were publicly traded (listed). This paper's analysis is based on five ratios introduced below. These ratios have been selected by the authors based on their expert judgment and literature review containing De Laurentis et al. (2010), Altman and Hotchkiss (2010), Campillo et al. (2013) or García Lara et al. (2009). The five selected financial ratios are:

EBITDA Margin presents a basic overview of a company's performance on the operational level. It is expressed as EBITDA over sales. EBITDA is computed as a difference between sales and the cost of materials, utilities, services and labour cost. Positive EBITDA Margin is considered to be a good operational outcome.

Cash Deficit indicator shows the level of a company's liquidity. It is computed as a real enterprise value of cash and its equivalents displayed in an annual balance sheet divided by the necessary operating cash and its equivalents. The necessary operating cash is expressed as $15 \%$ of company's current liabilities and it is derived from the general cash liquidity ratio.

Working Capital Ratio's construction is close to liquidity ratios but it fully omits cash, banking accounts, and their equivalents. The numerator contains the assets' items of working capital, specifically its inventories and receivables from selling the enterprise's products. The denominator consists of the liabilities' items of working capital, specifically payables to suppliers and employees. The value of Working Capital Ratio depends on an industry branch and corporate negotiation position with suppliers and customers. It has more a sense to analyse its deterioration in time. 
Debt Ratio is an indicator which is focused on enterprise leverage. It is computed as total liabilities divided by total assets (which are financed by liabilities or equity). The value of Debt Ratio is based on an industry branch or capital availability. It should be again analysed the time development. Extreme values exceeding 1 mean that the company has more debts than assets. The over-indebtedness described is considered to be risky.

Indicator ROA (Return on Assets) is expressed in this paper as the division of EBITDA by total assets to show the general operating effectiveness. Success of operational activities is expressed by positive values of ROA.

It should be noted that although the indicators above offer valuable tools of assessment, they cannot provide the best values due to the relative trade off effects. The consequence of which is that the final values of these indicators must be balanced. One solution offered is synthetic measures which are able to manage the related trade off effects. In situations where the conditions for the company are fiscally poor, the use of default indicators, such as bankruptcy models, are used and they combine several financial indicators focused on different financial health issues. The default models were constructed as a result of empirical observations and their functioning is based on probabilities (De Laurentis et al., 2010). The oldest complex model was published first in 1968 and called the Altman Z-Score (Altman, 1968). It is the most known model worldwide. It still remains highly accurate in its predictions in the Czech Republic, see Čámská (2016) or Karas and Režňáková (2015). This paper will be based on the Altman version for the enterprises not publicly traded. The analysis is based on version of Altman Z-Score mentioned in Altman and Hotchkiss (2010) and it is presented by equation 1 below.

$$
Z-\text { Score }=0.717 \times \frac{N W C}{A}+0.847 \times \frac{R E}{A}+3.107 \times \frac{E B I T}{A}+0.42 \times \frac{E}{L}+0.998 \times \frac{S}{A},
$$

where: NWC - Net Working Capital; $A$ - Assets; RE - Retained Earnings; EBIT - Earning before Interests and Taxes; $E$ - Equity in accounting value; $L$ - Liabilities; $S$ - Sales.

The computed value of the equation is compared with the evaluation ranges. According to Altman and Hotchkiss (2010) healthy enterprises have Z-Score higher than 2.9, grey zone is between $1.23-2.9$ and unhealthy enterprises' Z-Score is below 1.23.

\section{Results}

This chapter introduces results gained which describe the financial situation. First, the analysis is focused on the basic descriptive statistics of the five selected financial ratios which describe the enterprise's financial situation from the different perspectives. The results are in Table 2.

When comparing the mean and median, it is evident that the sample contains several outliers. It is especially observable when comparing the mean and $5 \%$ of the trimmed mean, which does not contain any of the outliers. The highest variance is connected with the EBITDA margin. The EBITDA margin should achieve positive values because it indicates the company has created profit. When the EBITDA margin is negative, it means that the company has not created profit from its operational activities. It will probably finish in red numbers 
Table 2. Mean and median of chosen ratios (source: author based on Bisnode MagnusWeb)

\begin{tabular}{|l|c|c|c|c|c|}
\hline & $\begin{array}{c}\text { EBITDA } \\
\text { Margin }\end{array}$ & Cash Deficit & $\begin{array}{c}\text { Working } \\
\text { Capital Ratio }\end{array}$ & Debt Ratio & ROA \\
\hline Mean & -54.64 & 0.89 & 5.01 & 1.76 & -0.09 \\
\hline $5 \%$ Trimmed Mean & -0.29 & 0.49 & 1.28 & 1.14 & -0.06 \\
\hline Median & -0.04 & 0.16 & 0.95 & 0.98 & -0.02 \\
\hline Variance & 265528.04 & 6.43 & 885.11 & 21.77 & 0.12 \\
\hline St. Deviation & 515.29 & 2.53 & 29.75 & 4.67 & 0.35 \\
\hline Minimum & -5199.25 & 0.00 & 0.00 & 0.00 & -2.10 \\
\hline Maximum & 0.89 & 23.70 & 295.21 & 45.93 & 2.00 \\
\hline
\end{tabular}

from all its activities because the operational activities are the backbone. According to the median more than half of the enterprises have a negative EBITDA margin.

Cash Deficit is an indicator which shows that the companies have serious problems in the area of the corporate liquidity. In our sample, 50\% of the companies had maximally $16 \%$ of the needed liquidity. It can be repeated that the level of needed liquidity is set up as 0.15 cash liquidity.

On the other hand, the working capital ratio reached much better results because the companies had non-financial current assets as inventories and receivables in the comparison to payables. If inventories and receivables are of good quality, they would be transferable in cash and their equivalents for reducing payables.

Debt Ratio shows that the companies used debts massively for their financing. The median proves that $50 \%$ of the companies use debts as their only financial source. When the value of debt ratio exceeds one it means that the company has more debts (liabilities) than assets. This situation is possible when the company has negative equity.

The ROA indicator computed with EBITDA in the numerator confirms the results of a negative EBITDA margin. In our sample, $50 \%$ of the companies finished in red numbers and they were not profitable.

Further the analysis will go deep and search for cross relations between the selected indicators. Negative EBITDA and the profitability of the companies are caused by high costs. When the cost and expenditures outweigh sales, the company finishes in red numbers. The main cost categories are the costs of materials, utilities and services accompanied by the labor costs in most companies. Table 3 shows the share of these cost categories on the companies' sales. The group cost of materials, utilities and services has a higher share. Leave aside the high mean value caused by the outliers, which confirms our observation regarding the EBITDA Margin. The median proves that $50 \%$ of the sample has this cost share lower than $78 \%$. These costs and expenditures partly have a variable character and therefore there is a way to change them when sales decrease. Conversely, the labor costs have a dominant fixed character and this change is much more difficult. The obvious conclusion is that companies need to manage their costs better.

The next step is the time analysis. Previous research works as Altman (1968) or Čámská (2017) prove that the financial situation is getting worse bankruptcy is coming closer. The 
Table 3. Shares of cost on the companies' sales (source: author based on Bisnode MagnusWeb)

\begin{tabular}{|l|c|c|}
\hline & Share of cost of material, utilities and services & Share of Labour Cost \\
\hline Mean & 91.66 & 4.26 \\
\hline 5\% Trimmed Mean & 0.94 & 0.26 \\
\hline Median & 0.78 & 0.21 \\
\hline
\end{tabular}

Table 4. Relative polarity of frequencies of selected indicators(source: author based on Bisnode MagnusWeb)

\begin{tabular}{|l|l|c|c|c|}
\hline \multirow{2}{*}{} & \multicolumn{3}{|c|}{ Before Insolvency Proposal } \\
\cline { 3 - 5 } \multicolumn{2}{|c|}{} & 1 Year & 2 Years & 3 Years \\
\hline \multirow{2}{*}{$\begin{array}{l}\text { Polarity of } \\
\text { EBITDA }\end{array}$} & Positive EBITDA & $26.7 \%$ & $42.9 \%$ & $43.8 \%$ \\
\cline { 2 - 5 } & Negative EBITDA & $73.3 \%$ & $57.1 \%$ & $56.3 \%$ \\
\hline $\begin{array}{l}\text { Polarity of Cash } \\
\text { Deficit }\end{array}$ & Cash Surplus & $13.3 \%$ & $21.4 \%$ & $20.8 \%$ \\
\cline { 2 - 5 } \begin{tabular}{l} 
Polarity of $\begin{array}{l}\text { Working Capital } \\
\text { Ratio }\end{array}$ \\
\cline { 2 - 5 }
\end{tabular} & Cash Deficit & $86.7 \%$ & $78.6 \%$ & $79.2 \%$ \\
\cline { 2 - 5 } Polarity of Equity & Negative Working Capital & $63.3 \%$ & $50.0 \%$ & $66.7 \%$ \\
\cline { 2 - 5 } & Positive Equity & $26.7 \%$ & $52.4 \%$ & $33.3 \%$ \\
\cline { 2 - 5 } & Negative Equity & $73.3 \%$ & $47.6 \%$ & $37.5 \%$ \\
\hline
\end{tabular}

data sample will be strictly divided into three time periods - one year, two years, or three years before the insolvency proposal. The company's financial situation is expressed using the indicators selected above and their main components. Outliers have been identified through their relative frequencies, which describe the polarity of the indicators. These results are divided in two groups. The first group shows the companies with positive outcomes as having positive EBITDA, cash surplus (more cash, and its equivalents, than the necessary level of liquidity), positive working capital (the surplus of current assets over short-term liabilities) and positive equity. The second group consists of the companies with negative outcomes in these indicators. The results are displayed in Table 4.

The analysis of the polarity of selected indicators shows that the primary EBITDA indicator, as the basic indicator of operational performance, had a shift in the polarity. The shift towards negative values is seen in the three year time period before the insolvency proposal. The indicator had a negative value for $56.3 \%$ of the enterprises in the three year time period before the proposal, but it had a negative value for $73.3 \%$ of the enterprises a year before the proposal. This means the operational performance deteriorated in the period leading up to the proposal. However, the operational performance was not satisfactory at the beginning of the period for most of the companies. Furthermore, it is evident that the companies had problems with the amount of cash and its equivalents. There is no observably significant deterioration of this indicator because about $80 \%$ of the companies suffered from a cash deficit during the analyzed time period. Primary non-cash components of working capital also have a worsening effect and it is remarkable for the EBITDA indicator. These observed results 
Table 5. Absolute and relative frequencies of polarity in the case of needed cash (source: author based on Bisnode MagnusWeb)

\begin{tabular}{|l|c|c|}
\hline & Frequency & Percent \\
\hline Cash Surplus & 23 & $19.2 \%$ \\
\hline Cash Deficit & 97 & $80.8 \%$ \\
\hline Total & 120 & $100.0 \%$ \\
\hline
\end{tabular}

confirm the three stage model developed by Farooq et al. (2018). However, the results for the working capital ratio are best one year before the proposal from all analyzed variables. The most significant shift is connected with equity. As indicated in the table above, less than $50 \%$ of the companies had negative equity in the two and three year time periods before the proposal, but the percentage increased to more than $70 \%$ only one year prior to the proposal.

The worst results gained were for the indicator expressing the level of cash liquidity. These values are unsatisfactory for the whole analyzed time period. The results above can be expanded by absolute and relative polarity frequencies of this indicator. The results can be found in Table 5.

As a result of the analysis, the majority of companies showed a cash deficit. This means that their cash (immediate) liquidity did not reach the required level of $15 \%$. This indicates potential solvency problems for the majority of businesses. This cash liquidity will be further analyzed in a relation to other indicators. The frequency analysis was used and the results gained are displayed in Table 6 below.

Table 6. Relative polarity frequencies of cash liquidity to other indicators (source: author based on Bisnode MagnusWeb)

\begin{tabular}{|l|l|c|c|}
\hline \multicolumn{2}{|c|}{} & Cash Surplus & Cash Deficit \\
\hline \multirow{2}{*}{ Polarity of EBITDA } & Positive EBITDA & $\mathbf{6 0 . 9} \%$ & $34.0 \%$ \\
\cline { 2 - 4 } & Negative EBITDA & $39.1 \%$ & $\mathbf{6 6 . 0} \%$ \\
\hline \multirow{2}{*}{$\begin{array}{l}\text { Polarity of Working } \\
\text { Capital Ratio }\end{array}$} & Positive Working Capital & $\mathbf{8 2 . 6 \%}$ & $46.4 \%$ \\
\cline { 2 - 4 } Polarity of Equity & Negative Working Capital & $17.4 \%$ & $\mathbf{5 3 . 6 \%}$ \\
\cline { 2 - 4 } & Positive Equity & $\mathbf{6 9 . 6 \%}$ & $45.4 \%$ \\
\cline { 2 - 4 } & Negative Equity & $30.4 \%$ & $\mathbf{5 4 . 6 \%}$ \\
\hline
\end{tabular}

The frequency analysis shows that two thirds of the companies with a deficit of the necessary cash also have negative EBITDA. Those companies with a negative EBITDA indicate an operating loss. In connection with the frequency of a cash deficit, this indicates that EBITDA (operational loss) has a significant impact on the insolvency indication. The other indicators show the same relationship; but their impacts are weaker. The majority of companies with a surplus of needed cash had positive values of all the other indicators at the same time. This is especially true in instances where the dependency between a cash surplus and positive non-cash working capital is very strong.

The most significant drop was observed in the case of equity during the analyzed time period (Table 7 below) and therefore interdependencies between equity and other variables 
are analyzed. Negative equity is caused by losses which occurred in past periods. When the value of these losses outweighs the value of other items of equity, the total equity is negative. It is already known that the majority of companies showed a cash deficit. The results achieved in terms of equity are more satisfactory because "only" half of the companies had negative equity (see Table 7 below). The consequence of which is that over-indebtedness is a smaller issue than cash deficit.

Table 7. Absolute and relative frequencies of polarity in the case of equity (source: author based on Bisnode MagnusWeb)

\begin{tabular}{|l|c|c|}
\hline & Frequency & Percent \\
\hline Positive Equity & 60 & $50 \%$ \\
\hline Negative Equity & 60 & $50 \%$ \\
\hline Total & 120 & $100 \%$ \\
\hline
\end{tabular}

Equity will be further analyzed in relation to other indicators. The frequency analysis is displayed in Table 8 . The results show that the companies with negative equity predominated by over $80 \%$ of the companies with negative EBITDA and a cash deficit. On the other hand, the relationship between negative equity and negative working capital is not so strong; although, it does show the same kind of relationship. The majority of companies with positive equity had positive values of profit (EBITDA) and reached a high level of working capital, but they had a cash deficit.

Table 8. Relative polarity frequencies of equity to other indicators (source: author based on Bisnode MagnusWeb)

\begin{tabular}{|l|l|c|c|}
\hline \multicolumn{2}{|c|}{} & Positive Equity & Negative Equity \\
\hline \multirow{2}{*}{ Polarity of EBITDA } & Positive EBITDA & $\mathbf{6 1 . 7 \%}$ & $16.7 \%$ \\
\cline { 2 - 4 } & Negative EBITDA & $38.3 \%$ & $\mathbf{8 3 . 3 \%}$ \\
\hline \multirow{2}{*}{ Polarity of Cash Deficit } & Cash Surplus & $26.7 \%$ & $11.7 \%$ \\
\cline { 2 - 4 } & Cash Deficit & $\mathbf{7 3 . 3 \%}$ & $\mathbf{8 8 . 3} \%$ \\
\hline $\begin{array}{l}\text { Polarity of Working } \\
\text { Capital Ratio }\end{array}$ & Positive Working Capital & $\mathbf{6 5 . 0 \%}$ & $41.7 \%$ \\
\cline { 2 - 4 } & Negative Working Capital & $35.0 \%$ & $\mathbf{5 8 . 3 \%}$ \\
\hline
\end{tabular}

The values gained by selected indicators showed negative performance. Besides the frequency analysis, we have used another tool for our examination, i.e. the Altman Z-Score is used. The ability of the Altman Z-Score to predict the likelihood of bankruptcy has been confirmed in many papers about Czech enterprises, specifically Čámská (2016), Karas and Režńáková (2015) or Klečka and Scholleová (2010). Absolute and relative frequencies of the Altman Z-Score zones (healthy, grey and unhealthy) are shown in Table 9.

The results show that over $90 \%$ of the companies were not classified as healthy because the financial performance belonged to the grey or, even worse, the unhealthy zone. Less than $6 \%$ of the companies were classified as healthy according to the Altman Z-Score. The 
Table 9. Frequency of Altman Z-Score (source: author based on Bisnode MagnusWeb)

\begin{tabular}{|l|c|c|c|c|}
\hline & Frequency & Percent & Valid Percent & $\begin{array}{c}\text { Cumulative } \\
\text { Percent }\end{array}$ \\
\hline$>2.9$ - Healthy Company & 7 & $5.8 \%$ & $5.8 \%$ & $5.8 \%$ \\
\hline $1.23-2.9$ - Grey Zone & 25 & $20.8 \%$ & $20.8 \%$ & $26.7 \%$ \\
\hline$<1.23$ - Unhealthy Company & 88 & $73.3 \%$ & $73.3 \%$ & $100.0 \%$ \\
\hline Total & 120 & $100.0 \%$ & $100.0 \%$ & \\
\hline
\end{tabular}

development of financial indicators has already proved that the financial situation has deteriorated during the analyzed time period. Therefore the development of Altman Z-Score will be analyzed as well. Table 10 includes descriptive statistics of the final value of the Altman Z-Score. The time periods of one, two or three year periods are strictly separated before the insolvency proposal.

Table 10. Descriptive statistics of Altman Z-Score (source: author based on Bisnode MagnusWeb)

\begin{tabular}{|c|c|c|c|c|}
\hline & \multicolumn{3}{|c|}{ Before Insolvency Proposal } \\
\hline & & 1 Year & 2 Years & 3 Years \\
\hline \multicolumn{2}{|l|}{ Median } & -1.58 & 0.26 & 0.53 \\
\hline \multicolumn{2}{|l|}{ Variance } & 44.82 & 3.36 & 14591.47 \\
\hline \multicolumn{2}{|c|}{ St. Deviation } & 6.69 & 1.83 & 120.80 \\
\hline \multicolumn{2}{|l|}{ Minimum } & -33.74 & -4.51 & -54.52 \\
\hline \multicolumn{2}{|l|}{ Maximum } & 5.98 & 3.71 & 840.72 \\
\hline \multirow{3}{*}{ Percentiles } & 25 & -2.75 & -0.87 & -0.51 \\
\hline & 50 & -1.58 & 0.26 & 0.53 \\
\hline & 75 & 0.98 & 1.32 & 1.49 \\
\hline
\end{tabular}

The Altman Z-Score presents a bankruptcy model with the highest worldwide popularity. Descriptive statistics contained in table 12 prove that financial performance of a majority of the companies was very poor. The time period does not play such an important role because the financial performance is poor in all three time periods. A value lower than 1.23 (unhealthy zone) is reached by more than $50 \%$ of the analyzed units in all three time periods. For the one year period before the insolvency proposal, this is valid for more than $75 \%$ of the cases. On the other hand, according to the maximal values, there are healthy units classified in all three time periods. Unfortunately, their occurrence is limited.

\section{Discussion}

The selected indicators and the bankruptcy model of the Altman Z-Score presented very low financial performance of the companies included in the analyzed data sample. Unfortunately, it means that the companies enter the insolvency proceeding with very bad financial results and this could have a serious consequence. The poor financial situation 
of a company could decrease the probability of successful reorganization (rescue) even though the reorganization is prepared before the beginning of the insolvency proposal. On the other hand, the prepared reorganization plan and informing creditors in advance increase the chance of a successful rehabilitation according to the Insolvency Act. The process is quicker because negotiations have already taken place. However, this paper has its limitations which should be mentioned. The first limitation is the sample size. The sample contains 120 annual financial statements which describe 53 companies in total. Partly it is caused by unpublished disclosures (Bokšová \& Randáková, 2013). The second limitation is that the reorganization principle is hardly used in the Czech Republic (Smrčka et al., 2013) and there are not many more cases which can be classified as the pre-packed insolvencies. The third limitation is the sample heterogeneity which is observable when comparing the size of the companies, the industry branches and the year of the insolvency proposal. It is predominantly in the period of economic crisis when the insolvency proposals are submitted. Such period is specific given the overall economic conditions (Malega \& Horvath, 2017; Cihak, 2009). Other limitations result from the conditions in the Czech Republic, not only legal but also institutional. The authors analyzing quality of the entrepreneurial environment in the Czech Republic mention that there are significant barriers (Cepel et al., 2018; Ključnikov et al., 2017).

The specific results of the conducted analysis show low financial performance of the pre-packed insolvency cases. It is partly surprising because of the special position of the prepacks already discussed. It proves findings that Czech companies enter insolvency proceedings too late and they are completely empty of property (Kislingerová et al., 2013; Cámská, 2013). On the other hand, these results lead to a consequence that the financial situation is not the key component for the creditors and they approve the reorganization regardless of the financial conditions. There have to exist other motives for creditors and the approvals of the reorganization principle.

\section{Conclusions}

This paper was focused on the financial situation of the companies entering insolvency proceedings with the already prepared and approved reorganization plan (also called pre-packed insolvency) in the Czech Republic. These insolvency cases are solved according to Czech insolvency law which was highly modernized in 2008 following the models from other developed countries. The financial health or performance of a company was assessed using financial ratios and variables such as the EBITDA margin, the cash liquidity ratio, the working capital ratio, the debt ratio and ROA accompanied by the bankruptcy model: the Altman $\mathrm{Z}$-Score. The results of these chosen indicators showed that most of the companies had very poor and weak financial performance three or two years before the insolvency proposal. It can be stated that the companies are in the last stage of the corporate crisis when they prepare the reorganization plan. The financial rehabilitation should be realized much earlier and it does not matter if it is or isn't the insolvency reorganization. It is difficult to answer why the companies react so late. The first systemic explanation could be the motivation of managers who want to hide their failure. If the managers are also the company's owners, they do not 
want to see the real situation. This means that they could lose their own company which they have been building for decades. We cannot exclude considerations about motivation to harm the creditors.

Further research directions could be based on financial results of these analyzed prepacked insolvencies. The procedure itself takes several years and therefore there is not available a statistically significant number of the finished prepacks yet. First, the question of general proceedings' outcomes remain. Several prepacks have been already transferred into liquidation without sustaining of going concern principle. These experiences also occur in the case of traditional reorganization. The usual way of reorganization is the preparation of the reorganization plan after the insolvency proposal. This prolongs the solution and contributes to possible further deterioration. It could be considered that the prepacks should achieve better results because of quicker solution and declared creditors' cooperation. Results of these two approaches (prepacks versus classical reorganization) should be compared and possible consequences should be derived. It can have consequences for legal framework and recommendations for system creditors such as financial institutions, providers of utilities. Second, it is necessary to prove if there is any dependency between financial situation before insolvency declaration and the proceedings' outcomes such as satisfactory level for creditors, time spent, and number of workplaces retained.

Limitations of this paper stem from the size of the data sample, from the focus on the Czech Republic only which is connected with valid national legal framework and data availability. The last limitation is based on the analysis of pre-pack insolvencies before the insolvency proceedings. New insight will be provided when further research comparing the results of insolvency proceedings is conducted.

\section{Funding}

This work was supported by the < The Technology Agency of the Czech Republic $>$ under Grant [The development of preventive and insolvency restructuring of firms in financial difficulties, the possibility of increasing the use and success of these procedures by setting up an early warning system and establishing procedures for preventive restructuring No. TL02000467].

\section{Disclosure statement}

Author declares that he does not have any competing financial, professional, or personal interests from other parties.

\section{References}

Altman, E. I., \& Hotchkiss, E. (2010). Corporate financial distress and bankruptcy: Predict and avoid bankruptcy, analyze and invest in distressed debt. John Wiley \& Sons.

Altman, E. I. (1968). Financial ratios, discriminant analysis and the prediction of corporate bankruptcy. The Journal of Finance, 23(4), 589-609. https://doi.org/10.1111/j.1540-6261.1968.tb00843.x 
Appiah, K. O., Chizema, A., \& Arthur, J. (2015). Predicting corporate failure: a systematic literature review of methodological issues. International Journal of Law and Management, 57(5), 461-485. https://doi.org/10.1108/IJLMA-04-2014-0032

Armour, J., Hertig, G., \& Kanda, H. (2009). Transactions with creditors. In R. Kraakman, et al. (Eds.), The anatomy of corporate law: A comparative and functional approach (pp. 115-151). Oxford University Press.

Ayotte, K. M., \& Morrison, E. R. (2009). Creditor control and conflict in Chapter 11. Journal of Legal Analysis, 1(2), 511-551. https://doi.org/10.1093/jla/1.2.511

Balcaen, S., \& Ooghe, H. (2006). 35 years of studies on business failure: an overview of the classic statistical methodologies and their related problems. The British Accounting Review, 38(1), 63-93. https://doi.org/10.1016/j.bar.2005.09.001

Bisnode MagnusWeb (n.d.). Pre-paid corporate database MagnusWeb. https://magnusweb.bisnode.cz/

Bokšová, J., \& Randáková, M. (2013). Zveřejňují podniky, které procházejí insolvenčním řízením, své účetní závěrky? (Diskuse ke zveřejňování účetních závěrek). Český finanční a účetní časopis, 8(4), 164-171. https://doi.org/10.18267/j.cfuc.364

Bork, R. (2012). Rescuing companies in England and Germany. Oxford University Press Oxford.

Branch, B. (2002). The costs of bankruptcy: A review. International Review of Financial Analysis, 11(1), 39-57. https://doi.org/10.1016/S1057-5219(01)00068-0

Campillo, J. P., Serer, G. L., \& Ferrer, E. V. (2013). Validez de la información financiera en los procesos de insolvencia. Un estudio de la pequeña empresa española. Cuadernos de Economía y Dirección de la Empresa, 16(1), 29-40. https://doi.org/10.1016/j.cede.2012.05.001

Cera, G., Belas, J., \& Zapletalikova, E. (2019). Explaining business failure through determinist and voluntarist perspectives. Serbian Journal of Management, 14(2), 257-275. https://doi.org/10.5937/sjm14-23348

Čámská, D. (2016). Accuracy of models predicting corporate bankruptcy in a selected industry branch. Ekonomický ćasopis, 64(04), 353-366.

Č́mská, D., \& Klečka, J. (2020). Comparison of prediction models applied in economic recession and expansion. Journal of Risk and Financial Management, 13(3), 52. https://doi.org/10.3390/jrfm13030052

Čámská, D. (2015). Impact of the Czech changing economic environment on bankruptcy models. International Advances in Economic Research, 21(1), 117-119. https://doi.org/10.1007/s11294-014-9481-0

Čámská, D. (2017). Time postponents of classical corporate bankruptcy models. In T. Löster \& T. Pavelka (Eds.), 11th International days of statistics and economics (pp. 264-272). Melandrium.

Čámská, D. (2013). Základní charakteristiky podniků v insolvenci. In P. Jedlička (Eds.), Sborník recenzovaných př́spěvků z mezinárodní konference Hradecké ekonomické dny (pp. 83-88). Univerzita Hradec Králové, Hradec Králové, Czech Republic.

Cepec, J., \& Grajzl, P. (2019). Measuring the effectiveness of bankruptcy institutions: filtering failures in Slovenian financial reorganizations. Journal of Institutional Economics, 15(3), 553-567. https://doi.org/10.1017/S1744137418000437

Cepel, M., Stasiukynas, A., Kotaskova, A., \& Dvorsky, J. (2018). Business environment quality index in the SME segment. Journal of Competitiveness, 10(1), 21-40. https://doi.org/10.7441/joc.2018.02.02

Cihak, M. (2009). Financial crisis (introduction). Czech Journal of Economics and Finance, 59(6), 502506.

Czech National Bank. (2019). Central bank exchange rate fixing. https://www.cnb.cz/cs/financni-trhy/ devizovy-trh/kurzy-devizoveho-trhu/kurzy-devizoveho-trhu/ 
De Laurentis, G., Maino, R., \& Molteni, L. (2010). Developing, validating and using internal ratings. John Wiley \& Sons. https://doi.org/10.1002/9780470971901

De Weijs, R., \& Baltjes, M. (2018). Opening the door for the opportunistic use of interim financing: A critical assessment of the EU Draft Directive on Preventive Restructuring Frameworks. International Insolvency Review, 27(2), 223-254. https://doi.org/10.1002/iir.1305

Dobeš, K., Kot, S., Kramoliš, J., \& Sopková, G. (2017). The perception of governmental support in the context of competitiveness of SMEs in the Czech Republic. Journal of Competitiveness, 9(3), 34-50. https://doi.org/10.7441/joc.2017.03.03

Eidenmüller, H. (2017). Contracting for a European insolvency regime. European Business Organization Law Review, 18(2), 273-304. https://doi.org/10.1007/s40804-017-0067-1

Eidenmüller, H., \& van Zwieten, K. (2015). Restructuring the European business enterprise: the European Commission's Recommendation on a new approach to business failure and insolvency. European Business Organization Law Review, 16(4), 625-667.

https://doi.org/10.1007/s40804-016-0042-2

Eklund, J., Levratto, N., \& Ramello, G. B. (2020). Entrepreneurship and failure: two sides of the same coin?. Small Business Economics, 54, 373-382. https://doi.org/10.1007/s11187-018-0039-z

European Commission. (2013). Communication from the Commission to the European Parliament, the Council, the European Economic and Social Committee and the Committee of the Regions Entrepreneurship 2020 Action Plan Reigniting the Entrepreneurial Spirit in Europe.

https://eur-lex.europa.eu/legal-content/EN/TXT/?uri=CELEX:52012DC0795

European Parliament, \& Council of the European Union. (2016). Proposal for a Directive of the European Parliament and of the Council on Preventive Restructuring Frameworks, Second Chance and Measures to Increase the Efficiency of Restructuring, Insolvency and Discharge Procedures and Amending Directive 2012/30/EU. https://eur-lex.europa.eu/legal-content/EN/TXT/?uri=COM:2016:0723:FIN

Farooq, U., Jibran Qamar, M. A., \& Haque, A. (2018). A three-stage dynamic model of financial distress. Managerial Finance, 44(9), 1101-1116. https://doi.org/10.1108/MF-07-2017-0244

Fisher, T. C., \& Martel, J. (2004). Empirical estimates of filtering failure in court-supervised reorganization. Journal of Empirical Legal Studies, 1(1), 143-164. https://doi.org/10.1111/j.1740-1461.2004.00005.x

García Lara, J. M., Osma, B. G., \& Neophytou, E. (2009). Earnings quality in ex-post failed firms. Accounting and Business Research, 39(2), 119-138. https://doi.org/10.1080/00014788.2009.9663353

Hlaváček, P., Zambochova, M., \& Sivicek, T. (2015). The influence of the institutions on entrepreneurship development: Public support and perception of entrepreneurship development in the Czech Republic. Amfiteatru Economic Journal, 17(38), 408-421.

Jordan, B. D., Westerfield, R. W., \& Ross, S. A. (2011). Corporate finance essentials. McGraw-Hill Irwin.

Kapliński, O. (2008). Usefulness and credibility of scoring methods in construction industry. Journal of Civil Engineering and Management, 14(1), 21-28. https://doi.org/10.3846/1392-3730.2008.14.21-28

Karas, M., \& Režňáková, M. (2015). The prediction capabilities of bankruptcy models in a different environment: An example of the Altman model under the conditions in the visegrad group countries. Ekonomický časopis, 63(6), 617-633.

Kislingerová, E., Richter, T., \& Smrčka, L. (2013). Insolvenční praxe v České republice: v období 20082013. C.H. Beck.

Klečka, J. \& Scholleová, H. (2010). Bankruptcy models enunciation for Czech glass making firms. Economics and Management, 15, 954-959.

Ključnikov, A., \& Popesko, B. (2017). Export and its financing in the SME segment. Case study from Slovakia. Journal of Competitiveness, 9(1), 20-35. https://doi.org/10.7441/joc.2017.01.02

Ključnikov, A., Kozubíková, L., \& Sopková, G. (2017). The payment discipline of small and medium-sized enterprises. Journal of Competitiveness, 9(2), 45-61. https://doi.org/10.7441/joc.2017.02.04 
Lee, S. H., Yamakawa, Y., Peng, M. W., \& Barney, J. B. (2011). How do bankruptcy laws affect entrepreneurship development around the world?. Journal of Business Venturing, 26(5), 505-520. https://doi.org/10.1016/j.jbusvent.2010.05.001

Levratto, N. (2013). From failure to corporate bankruptcy: a review. Journal of Innovation and Entrepreneurship, 2(1), 20. https://doi.org/10.1186/2192-5372-2-20

Leyman, B., Schoors, K. J., \& Coussement, P. (2011). Does court-supervised reorganization work? Evidence from post-confirmation firm failure. International Review of Law and Economics, 31(3), 149-168. https://doi.org/10.1016/j.irle.2011.05.001

Malega, J. \& Horvath, R. (2017). Financial stress in the Czech Republic: Measurement and effects on the real economy. Prague Economic Papers, 26(3), 257-268. https://doi.org/10.18267/j.pep.608

Parliament of the Czech Republic. (2006). Act No. 182/2006 Coll. on bankruptcy and settlement. https://www.zakonyprolidi.cz/cs/2006-182

Peng, M. W., Yamakawa, Y., \& Lee, S. H. (2010). Bankruptcy laws and entrepreneur-friendliness. Entrepreneurship Theory and Practice, 34(3), 517-530. https://doi.org/10.1111/j.1540-6520.2009.00350.x

Smrčka, L., \& Čámská, D. (2017). Methods of enforcing receivables and results in the Czech Republic. International Advances in Economic Research, 23(1), 125-126. https://doi.org/10.1007/s11294-016-9616-6

Smrčka, L., Arltová, M., \& Schönfeld, J. (2013). Příčiny neúspěchu prosazování sanačních postupů v insolvenční realitě. Politická ekonomie, 61(2), 188-208. https://doi.org/10.18267/j.polek.894

Tollenaar, N. (2017). The European Commission's Proposal for a Directive on Preventive Restructuring Proceedings. Insolvency Intelligence, 30(5). https://ssrn.com/abstract=2978137

Xie, B. (2016). Comparative insolvency law the pre-pack approach in corporate rescue (1st ed.). Edward Elgar Publishing. 